Article

\title{
Optimal Solar Power System for Remote Telecommunication Base Stations: A Case Study Based on the Characteristics of South Korea's Solar Radiation Exposure
}

\author{
Mohammed H. Alsharif * and Jeong Kim \\ Department of Electrical Engineering, College of Electronics and Information Engineering, Sejong University, \\ 209 Neungdong-ro, Gwangjin-gu, Seoul 05006, Korea; kimjeong@sejong.ac.kr \\ * Correspondence: malsharif@sejong.ac.kr; Tel.: +82-2-6935-2439; Fax: +82-2-3408-4329 \\ Academic Editor: Andrew Kusiak \\ Received: 15 July 2016; Accepted: 12 September 2016; Published: 15 September 2016
}

\begin{abstract}
This paper aims to address both the sustainability and environmental issues for cellular base stations in off-grid sites. For cellular network operators, decreasing the operational expenditures of the network and maintaining profitability are important issues. Hence, this study addresses the feasibility of a solar power system based on the characteristics of South Korean solar radiation exposure to supply the required energy to a remote cellular base station. The HOMER is used to determine the optimum size of the system components, to perform an energy production analysis, and to analyse the cost details of the project. The simulation results show that the proposed solar power system can achieve total operational expenditure savings of up to $48.6 \%$ by using sustainable and clean energy. This result means a significant long-term benefit can be achieved for cellular network operators.
\end{abstract}

Keywords: PV System; cellular networks; solar base station; HOMER; OPEX; sustainable energy; clean energy; South Korea

\section{Introduction}

We are currently witnessing an unprecedented growth in the number of mobile subscribers in rural areas, which has prompted mobile network operators to expand their cellular networks to provide mobile service to subscribers in rural areas, increasing the profitability of the operators [1]. However, operational expenditures and greenhouse gas emissions are a major concern of the mobile network operators because diesel generators are typically used to power the off-grid cellular base stations in remote areas [2], which challenges mobile network operators to find an economically feasible alternative power source that is also environmentally friendly. With the current progress in renewable energy, the key features of a power source, such as the cost effectiveness, sustainability, and reliability, as well as reduction of the greenhouse gas emissions, can be met [3].

South Korea is located at a latitude between $34^{\circ} \mathrm{N}$ and $38^{\circ} \mathrm{N}$ and has excellent potential to use solar energy. The average daily solar radiation ranges from $2.474 \mathrm{kWh} \cdot \mathrm{m}^{-2}$ in December to $5.622 \mathrm{kWh} \cdot \mathrm{m}^{-2}$ in May [4,5]. Moreover, the solar radiation in South Korea is relatively high compared with other countries located at similar latitudes. For example, the annual average global horizontal irradiation of Jeonju (latitude $36^{\circ} \mathrm{N}$, longitude $127^{\circ} \mathrm{E}$ ) in South Korea is $4.01 \mathrm{kWh} \cdot \mathrm{m}^{-2}$, in contrast to the $3.64 \mathrm{kWh} \cdot \mathrm{m}^{-2}$ of Tokyo, which is located at a similar latitude but a longitude of approximately $139^{\circ} \mathrm{E}$ [5]. In addition, References [4,5] have shown that the wind speed in South Korea does not exceed $4 \mathrm{~m} / \mathrm{s}$. According to References [6,7], the wind speed is considered low, and a stand-alone solar power 
system would be useful for low DC-power demand applications (less than $2 \mathrm{~kW}$ ), such as cellular base stations.

The key contributions of this study are summarised as follows: (i) feasibility study of the solar power system to feed remote cellular base stations under various cases of daily solar radiation in South Korea; (ii) determination of the optimum criteria and the economic and technical feasibility of the solar power system using HOMER software; and (iii) economic comparison of the proposed solar power system vs. diesel generators.

This paper is organised as follows. Section 2 reviews the use of renewable energy in the telecommunication sector. Section 3 discusses the use of the solar energy to feed the off-grid base stations in South Korea. Section 4 describes the system architecture of a solar power system integrated with a cellular base station. Mathematical models, an overview of HOMER software, and the simulation setup are presented in Sections 5-7, respectively. Section 8 presents the optimisation results and discussion, and Section 9 presents the economic comparison of the proposed solar power system vs. the diesel generator. Section 10 concludes this paper.

\section{Overview of the Use of Renewable Energy in the Telecommunications Sector}

Solar energy was used extensively in the telecommunications industry in the 1970s for microwave repeaters to connect remote towns and homesteads to the telecommunication grid, allowing them to access the same radio, telephone and television services that their urban neighbours had long enjoyed. In addition, photovoltaic energy powered telecommunication satellite earth stations, rural telephony, and telephone exchanges [8]. However, this section discusses the renewable energy solutions in cellular communication technology; several studies have been conducted to help mobile network operators to achieve their ambition to maintain profitability while protecting the environment by shifting away the use of diesel generators to feed off-grid base stations. Figure 1 highlights the different studies that have been conducted to develop environmentally friendly cellular networks with low operational expenditures in different regions around the world.

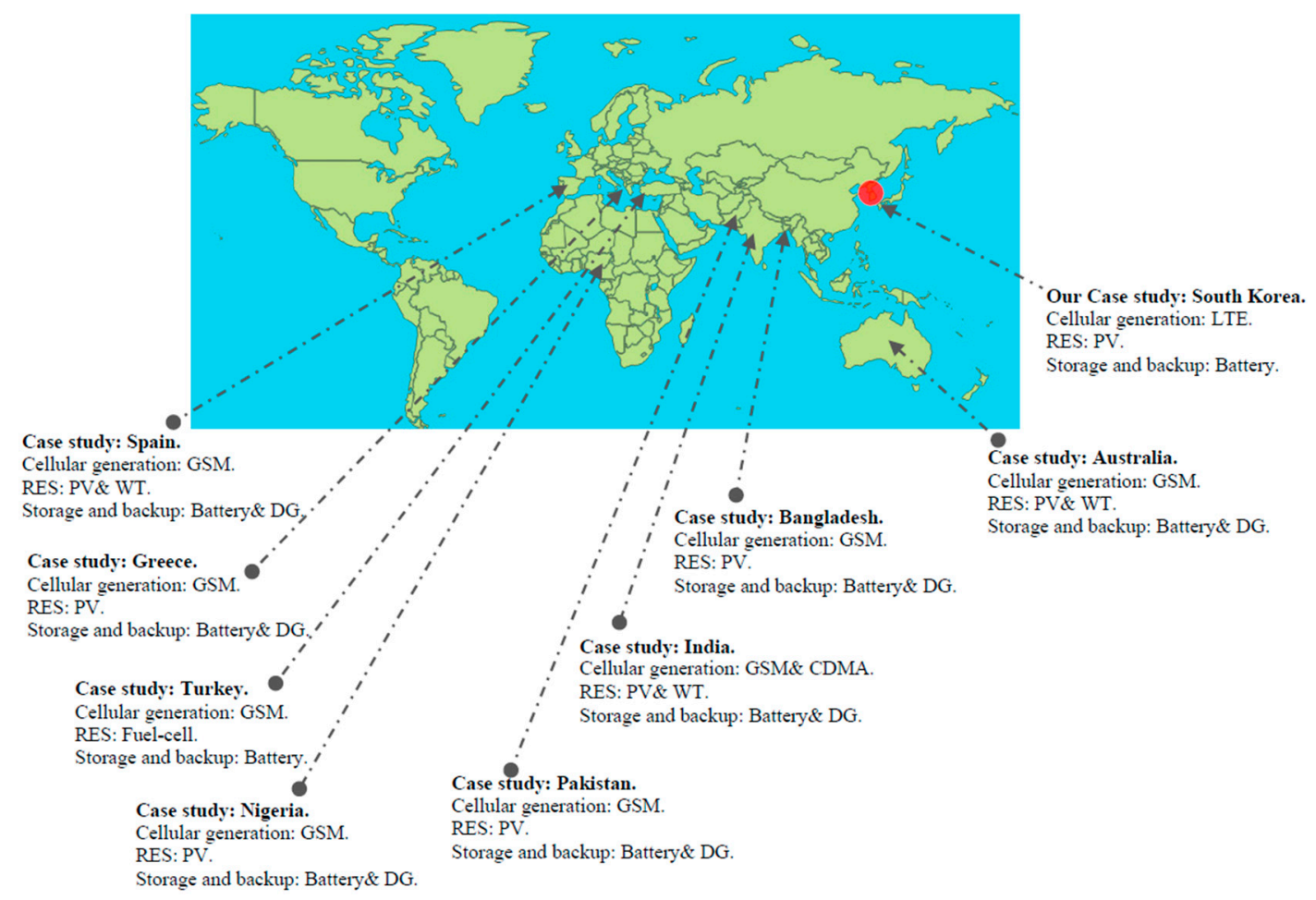

Figure 1. Summary of related works on energy optimisation strategies for cellular base stations [9-17]. 
This study addresses the sustainability of power sources for base stations in the fourth generation of cellular networks, which is called long-term evolution (LTE) and is considered the fastest development in mobile communication [18]. Figure 2 shows the number and locations of the LTE base stations deployed in South Korea by mobile operators, where SK Telecom has 52,000, LG U+ has 70,717, and $K T$ has 42,476 LTE base stations [19].

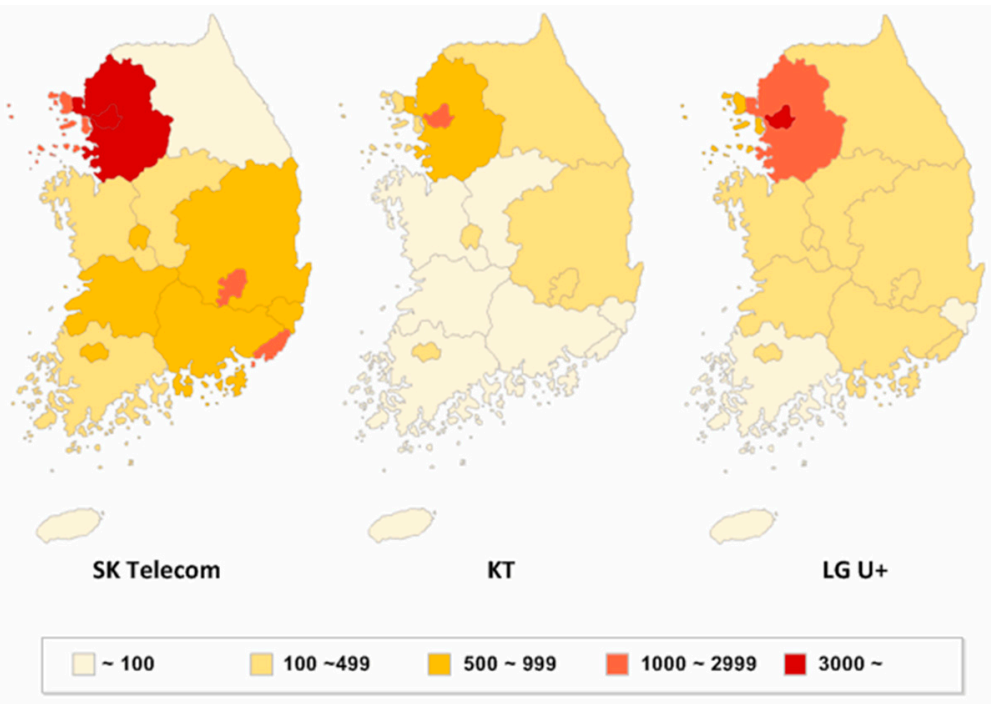

Figure 2. Map of the LTE base stations in South Korea [19].

\section{Potential of Applying Solar Energy in South Korea}

The average daily solar radiation in South Korea, which is located at a latitude between $34^{\circ}$ and $38^{\circ} \mathrm{N}$, is estimated to be $4.01 \mathrm{kWh} \cdot \mathrm{m}^{-2}$ and varies from $2.474 \mathrm{kWh} \cdot \mathrm{m}^{-2}$ in December to $5.622 \mathrm{kWh} \cdot \mathrm{m}^{-2}$ in May [4,5]. Monthly variation, as shown in Figure 3, is largely because of the shift in the elevation angle of the sun. Additionally, the long spell of rainy weather in early summer decreases the global horizontal irradiance in June and July.

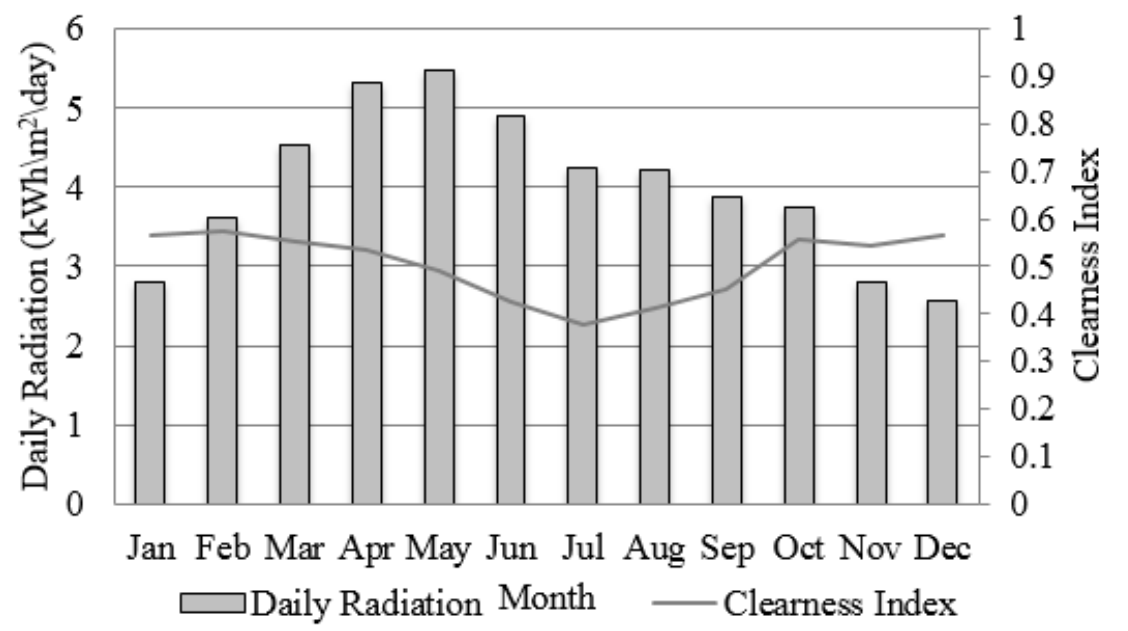

Figure 3. Monthly average solar global horizontal irradiance at $35.5^{\circ} \mathrm{N}$ latitude and $127.5^{\circ} \mathrm{E}$ longitude $[4,5]$.

Moreover, solar radiation in different areas of South Korea is shown in Figure 4. Relatively higher daily solar radiation of over $5 \mathrm{kWh} \cdot \mathrm{m}^{-2}$ can be obtained in the southwestern coastal area, including Jeju Island. In contrast, in the northwestern region around Seoul, daily solar radiation is lowered to 
approximately $4.7 \mathrm{kWh} \cdot \mathrm{m}^{-2}$, and Gochang, located at the western coast of South Korea, shows the lowest daily solar radiation of $4.48 \mathrm{kWh} \cdot \mathrm{m}^{-2}$.

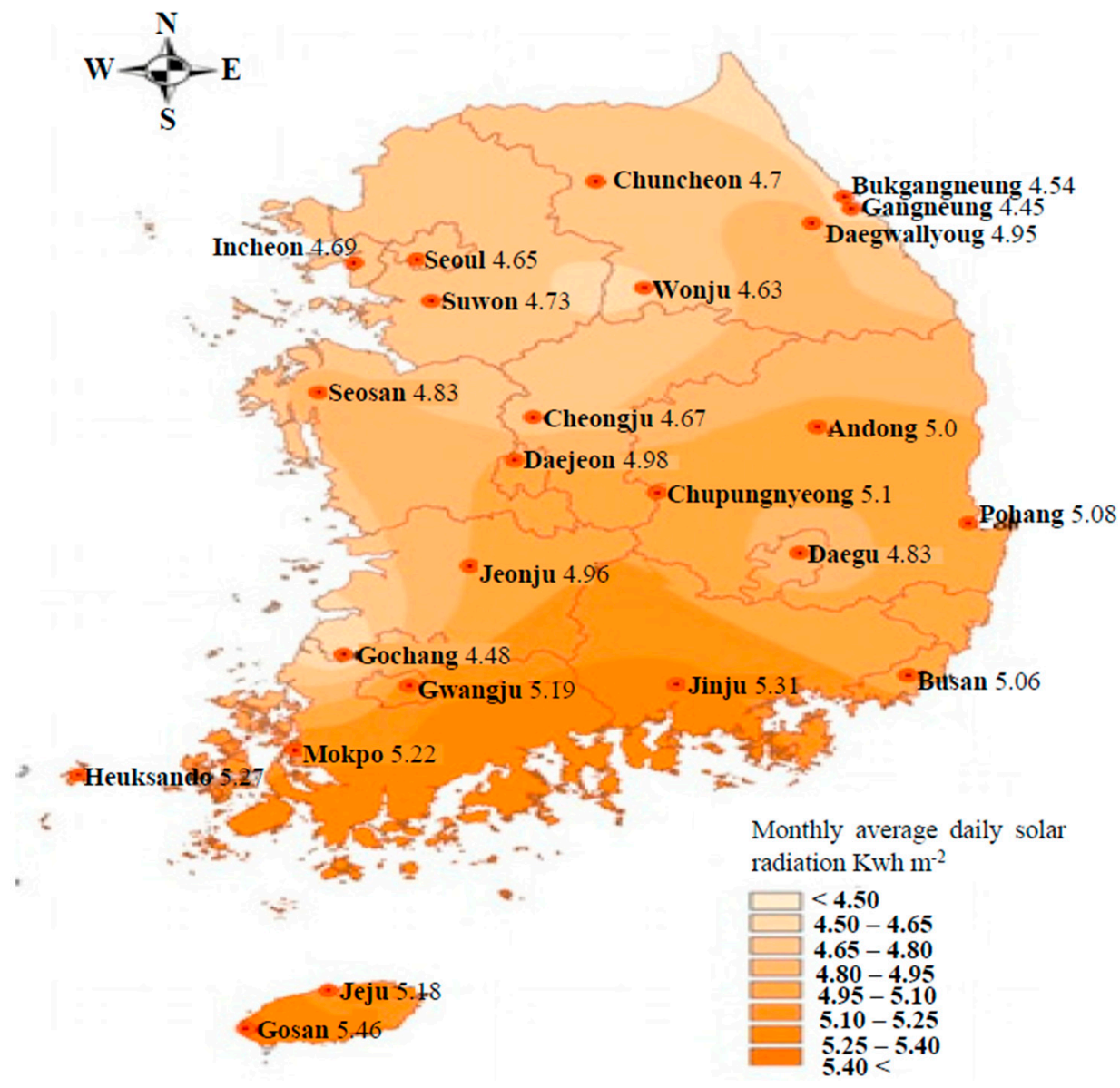

Figure 4. Monthly average daily solar radiation [20].

According to Figure 4, this study attempts to determine the optimum criteria for the solar energy systems for different values of solar radiation to cover all possible areas of South Korea: 4.0, 4.5, 4.6, 4.7, $4.8,4.9$, and $5.0 \mathrm{kWh} \cdot \mathrm{m}^{-2}$. The monthly average solar radiation values used in this study are obtained from the Korea Meteorological Administration (KMA) and the NASA Surface Meteorology and Solar Energy using the longitude and latitude of South Korea [4,5]. The energy production analysis and the cost details of the solar power system will be given based on the average daily solar radiation of South Korea, which is $4.0 \mathrm{kWh} \cdot \mathrm{m}^{-2}$.

\section{Barriers Facing the Spread of Photovoltaic (PV) System and Recommendations}

One of the major drawbacks of the PV system is that it is highly dependent on weather conditions; this system lacks stability because of the variation in solar radiation. As stated above, solar radiation in December is less than half of the solar radiation in May. This large seasonal fluctuation of solar radiation results in difficulties with using the PV system in South Korea. To ensure sufficient electrical energy, the PV capacity should be increased or an additional power generation system should be included, which may cause increased installation costs for the overall system. In addition, typhoons with heavy rain that occur in South Korea largely during the summer season will damage solar PV panels and their mounting structure. Continued maintenance by a trained engineer is necessary to maintain PV system performance for telecommunication applications. 


\section{System Model}

Figure 5 shows a model of a solar energy system integrated with an LTE-macro base station.

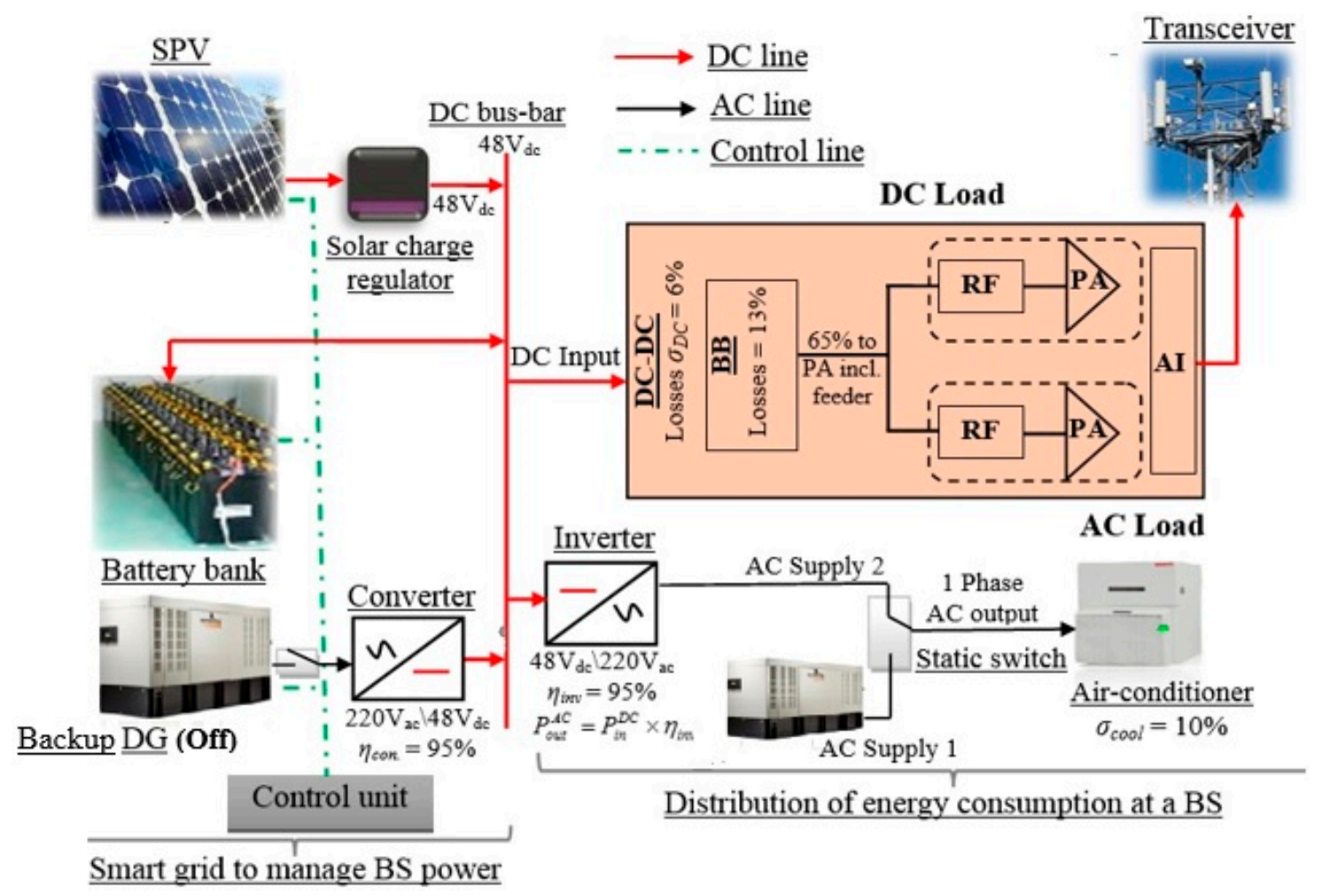

Figure 5. Sustainable LTE-macro base station model within a smart grid environment.

The solar panels feed the required energy to the LTE-macro base station. However, in case of a malfunction of the solar panels, resulting in an inability to provide the energy required to the LTE-macro base station, the battery bank compensates for the shortage of energy. If the battery bank reaches its maximum depth of discharge (DOD) and loses the ability to supply the LTE-macro base station the required energy, a backup diesel generator supplies energy to the LTE-macro base station. Hence, the diesel generator is suggested as a backup power source to secure the power supply during maintenance or in case of a malfunction in the system. The static switch monitors the power of the solar power system. If the output power is less than required to meet the AC loads, the AC loads switch to draw energy from the backup diesel generator.

\subsection{Long-Term Evolution (LTE)-Macro Base Station Subsystem and Power Consumption Modelling}

The base station in a cellular network is an access link between the core network and the mobile equipment (users); a base station site consists of a set of equipment, including a power amplifier, baseband unit, radio-frequency unit, power supply, and air conditioner. More details on the base station components can be found in [21].

An LTE-macro base station type is described in [22]. The mathematic equation for the power consumption of an LTE-macro base station is $P_{o p}=N_{T R X} \times\left[P_{P A}^{D C}+P_{R F}^{D C}+P_{B B}^{D C}\right] /\left(1-\sigma_{D C}\right)\left(1-\sigma_{c o o l}\right)$, where $N_{T R X}$ is the number of transceivers, $P_{P A}^{D C}$ is the power consumption by the power amplifier unit, $P_{R F}^{D C}$ is the power consumption by the radio-frequency unit, and $P_{P B}^{D C}$ is the power consumption by the baseband unit. $\sigma_{D C}$ and $\sigma_{c o o l}$ represent the DC-DC regulator and air conditioner losses, respectively. However, the power consumption of the air conditioner depends on the surroundings and the internal temperature of the LTE-macro base station cabinet. According to [22], $\sigma_{D C}$ is approximately $6 \%$, and $\sigma_{\text {cool }}$ is approximately $10 \%$. 
$P_{P A}^{D C}$ is a linear function of the base station transmission power $P_{t x}^{\max }$ and is equal to $P_{t x}^{\max } / \eta_{P A}$, where $\eta_{P A}$ is the PA efficiency. In general, both coverage and signal propagation fading are considered main factors in determining the transmission power of the base station. However, the simplified mathematical model to calculate the transmission power from the base station is $P_{t x}^{\max }=P_{o} \times\left(\mathrm{R} / R_{o}\right)^{a}$, where $\alpha$ is the path loss coefficient, $R$ is the actual coverage radius of the base station, and $P_{o}$ and $R_{o}$ are the normalised transmission power, which is $40 \mathrm{~W}$, and the normalised coverage radius, which is $1 \mathrm{~km}$ for a base station. Hence, the mathematic equation for the power consumption of the LTE-macro base station is $P_{o p}=N_{T R X} \times\left[\mathrm{P}_{o}\left(R / R_{o}\right) / \eta_{P A}+P_{R F}^{D C}+P_{B B}^{D C}\right] /\left(1-\sigma_{D C}\right)\left(1-\sigma_{c o o l}\right)$. In addition, the base station site includes a microwave dish $\left(P_{m c}\right)$ to connect the base station to the core network and lighting lamps $\left(P_{l m}\right)$. Hence, the final mathematic equation for the power consumption of the LTE-macro base station is,

$$
P_{B S}=\frac{N_{T R X}\left(\frac{P_{o}\left(\frac{R}{R_{o}}\right)^{\alpha}}{\eta_{P A}}+P_{R F}^{D C}+P_{B B}^{D C}\right)}{\left(1-\sigma_{D C}\right)\left(1-\sigma_{\text {cool }}\right)}+P_{m c}+P_{l m}
$$

Table 1 summarises the power consumption for different equipment at an LTE-macro base station with a $2 \times 2$ multiple-input and multiple-output antenna configuration with three sectors.

Table 1. Details of the power consumption for an LTE-macro base station [21,22].

\begin{tabular}{|c|c|c|c|}
\hline Item & Notation & Unit & LTE Base Station \\
\hline \multirow{3}{*}{ Power amplifier } & Transmit power, $P_{t x}^{\max }$ & Watt & 39.8 \\
\hline & PA efficiency, $\mu$ & $\%$ & 38.8 \\
\hline & $P_{P A}^{D C}=\frac{P_{t x}^{\max }}{\mu}$ & Watt & 102.6 \\
\hline Radio-frequency & $P_{R F}^{D C}$ & Watt & 10.9 \\
\hline Baseband & $P_{B B}^{D C}$ & Watt & 14.8 \\
\hline \multirow{2}{*}{ Losses } & $\sigma_{D C}$ & $\%$ & 6 \\
\hline & $\sigma_{\text {cool }}$ & $\%$ & 10 \\
\hline \multicolumn{2}{|c|}{ Total per TRX $=\frac{P_{P A}^{D C}+P_{R F}^{D C}+P_{B B}^{D C}}{\left(1-\sigma_{D C}\right)\left(1-\sigma_{c o o l}\right)}$} & Watt & 151.65 \\
\hline \multicolumn{2}{|c|}{ Sectors $\left(N_{\text {Sect }}\right)$} & $\#$ & 3 \\
\hline \multicolumn{2}{|c|}{ Antennas $\left(N_{A n t}\right)$} & $\#$ & 2 \\
\hline \multicolumn{2}{|c|}{$\mathrm{N}_{\text {TRX }}=N_{\text {Sect }} \times N_{\text {Ant }}$} & $\#$ & 6 \\
\hline \multicolumn{2}{|c|}{ Total number of $\mathrm{N}_{\mathrm{TRX}}$ chains, $\mathrm{P}_{\mathrm{op}}=\mathrm{N}_{\mathrm{TRX}} \times$ Total per TRX } & Watt & 909.93 \\
\hline \multicolumn{2}{|c|}{ Microwave link $\left(P_{m c}\right)$} & Watt & 80 \\
\hline \multicolumn{2}{|c|}{ Lamps $\left(P_{l m}^{A C}\right)$} & Watt & 40 \\
\hline
\end{tabular}

In addition, Figure 6 shows the hourly load profiles. The AC load includes a $91 \mathrm{~W}$ air conditioner that represents $10 \%$ of $P_{\text {in }}$ and $40 \mathrm{~W}$ lighting that operates from 7 p.m. to 7 a.m. The DC load includes a base station ( $P_{o p}$ minus air conditioner equals $819 \mathrm{~W}$ and microwave backhaul equals $80 \mathrm{~W}$ ).

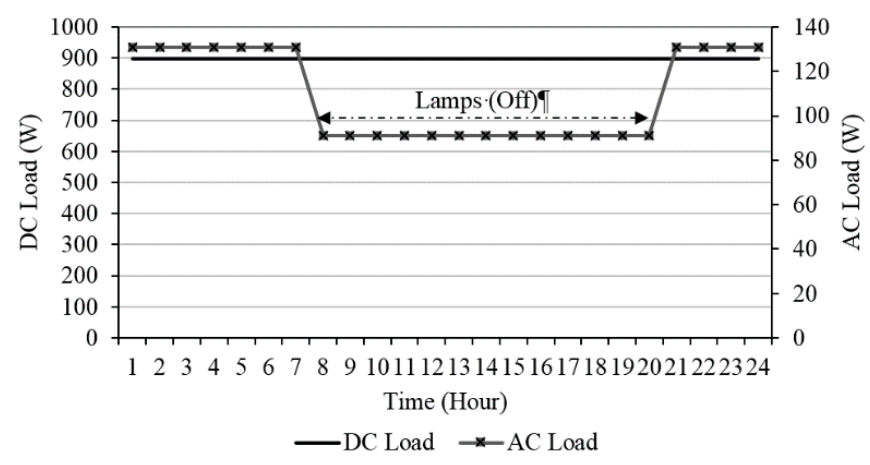

Figure 6. Hourly load profile for an LTE-macro base station. 


\subsection{Solar Power Subsystem}

The elements of the solar power system are listed below; these elements are designed for easy installation and disassembly. Moreover, due to the significant development in solar technology, these components are designed with high efficiency and low losses to contribute to energy saving.

a) Solar panels: absorb shortwave irradiance and convert it into direct current (DC) electricity [7].

b) Solar regulator charger: control unit responsible for the regulation of the unregulated DC output voltage of the solar array to regular DC voltage that is compatible with the load and the battery. In this study, the DC load (LTE-macro base station) voltage is $48 V_{d c}$.

c) Batteries: store excess energy from the solar arrays to be used at night or when the power output of the solar panels is not sufficient to cover the LTE-macro base station load. A charge control unit is added to protect the batteries by regulating the charging and discharging process and maintaining the battery lifecycle [7].

d) Inverter: converts the $48 \mathrm{DC}$ voltage of the DC bus-bar into 220 alternating current (AC) voltage that is used to feed the AC load in the base station [7].

e) Control unit: key element in the solar power system that manages and controls the power flow of the different elements in the solar power system to meet the demands of the LTE-macro base station load.

\section{Mathematical Model}

This section presents the details of the mathematical model of a solar power system proposed to feed an LTE-macro base station.

\subsection{Photovoltaic System}

HOMER is used to calculate the output energy of the solar panels $\left(Q_{P V}\right)$ according to the following equation [23],

$$
Q_{P V}=Y_{P V} \times P S H \times f_{P V}
$$

where $Y_{P V}$ is the capacity of the PV array, and PSH is the peak solar hour [24]. $f_{P V}$ is the PV derating factor, which reflects the impact of dust, wire losses, temperature, and other factors that can affect the output energy of the solar array.

\subsection{Battery Model}

The key features of the battery model used in this study, such as the capacity, voltage, charge current, efficiency, and state of charge (SOC), are shown in Figure 7. More details can be found in [25].

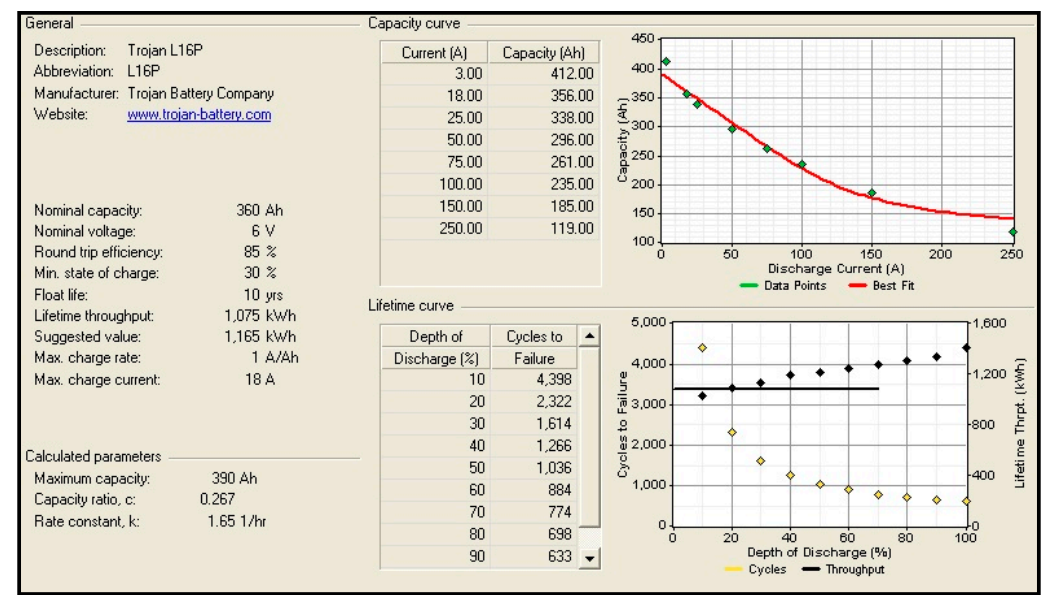

Figure 7. The key features of the "Trojan L16P" battery model. 
The maximum state of charge $\left(S O C_{\max }\right)$ of the battery bank is equal the nominal capacity of the battery bank, while the minimum state of charge $\left(S O C_{\min }\right)$ is $30 \%$, which means the maximum energy that will be delivered from the "Trojan L16P" battery bank is 70\%. This value is called the depth of discharge $(D O D)$ and is expressed as follows [23],

$$
D O D=1-S O C_{\min }
$$

The battery bank autonomy $\left(A_{\text {batt }}\right)$ is an important factor that represents the potential number of days that the battery bank can feed the required energy load without contribution from the solar panels, and it is expressed as the ratio of the battery bank size to the LTE-macro base station load [23],

$$
A_{\text {batt }}=\frac{N_{\text {batt }} \times V_{\text {nom }} \times Q_{\text {nom }}\left(1-\frac{S O C_{\text {min }}}{100}\right)(24 h / d)}{L_{\text {prim-avg }}(1000 W h / k W h)}
$$

where $N_{\text {batt }}$ is the number of batteries, $V_{\text {nom }}$ and $Q_{\text {nom }}$ are the voltage and capacity of a single battery, respectively, and $L_{\text {prim-avg }}$ is the average daily LTE-macro base station load.

The battery lifecycle $\left(R_{\text {batt }}\right)$ is another important issue that can reduce the total replacement cost during the project lifecycle. The throughput and the battery float life are the main factors that affect the battery lifecycle. The battery lifecycle is calculated by HOMER based on the following equation [23],

$$
R_{\text {batt }}=\min \left(\frac{N_{\text {batt }} \times Q_{\text {life }}}{Q_{\text {thr }}}, R_{\text {batt }, f}\right)
$$

where $Q_{\text {life }}$ is the lifetime throughput of a single battery, $Q_{t h r}$ is the annual battery throughput, and $R_{\text {batt }, f}$ is the battery float life.

\section{HOMER Modelling Software}

HOMER [23] is the optimisation software used in this study to determine the optimal solar power system that satisfies user-specified constraints with the lowest net present cost NPC, which represents all the costs that occur within the project lifecycle, including the initial costs (IC), replacement costs, and O\&M costs. Figure 8 summarises the main parts of the HOMER simulation, inputs, optimisation, and outputs. The NPC is computed as follows,

$$
N P C=\frac{T A C}{C R F}
$$

where $T A C$ is the total annualised cost, and CRF is the capital recovery factor (CRF), which is,

$$
C R F=\frac{i(1+i)^{n}}{(1+i)^{n}-1}
$$

where $n$ is the project lifecycle, and $i$ is the annual real interest rate.

The discount factor $\left(f_{d}\right)$ is a ratio used to calculate the present value of cash flow that occurs in any year of the project lifetime and is expressed as follows,

$$
f_{d}=\frac{1}{(1+i)^{n}}
$$

NPC also includes the salvage value (S), which is calculated as follows,

$$
S=\operatorname{rep}\left(\frac{r e m}{\operatorname{comp}}\right)
$$


where rep, rem, and comp are the replacement cost of the component, the remaining lifetime, and the lifetime of the component, respectively.

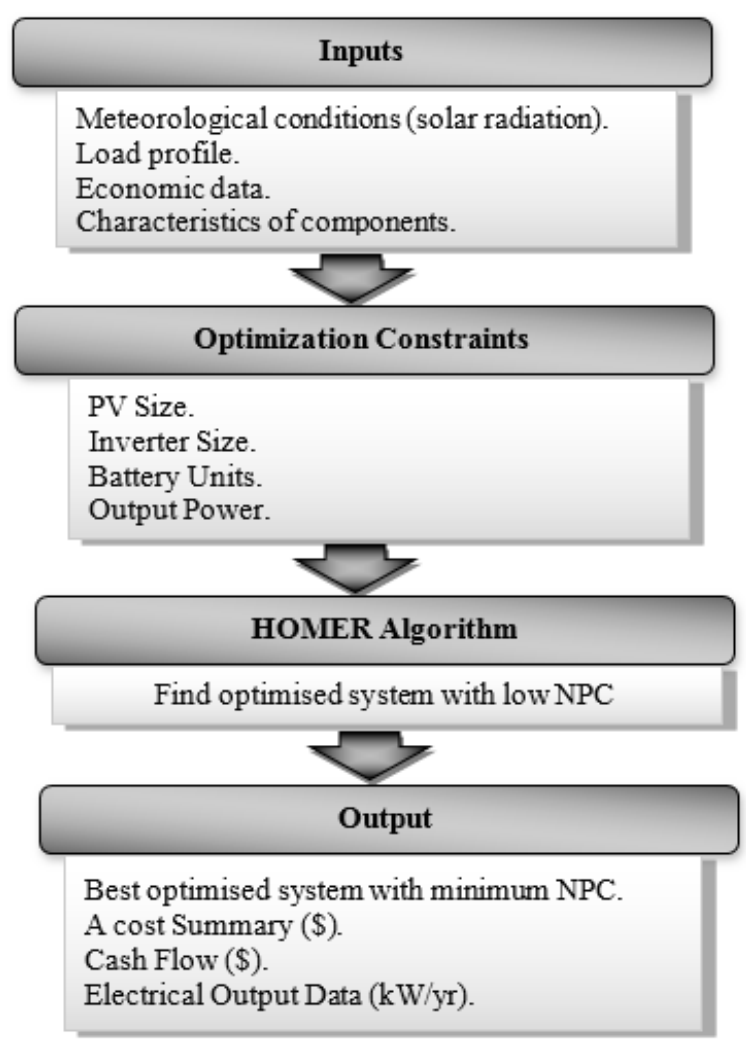

Figure 8. HOMER simulation approach.

\section{Simulation Configuration}

\subsection{Load Profile}

The LTE-macro base station load is critical for designing a reliable and efficient system. Sizing and modelling of the solar power system depend on the load profile. We used 24-h load values for 365 days for an accurate analysis. The seasonal load profiles for both the DC and AC loads are shown in Figure 9.

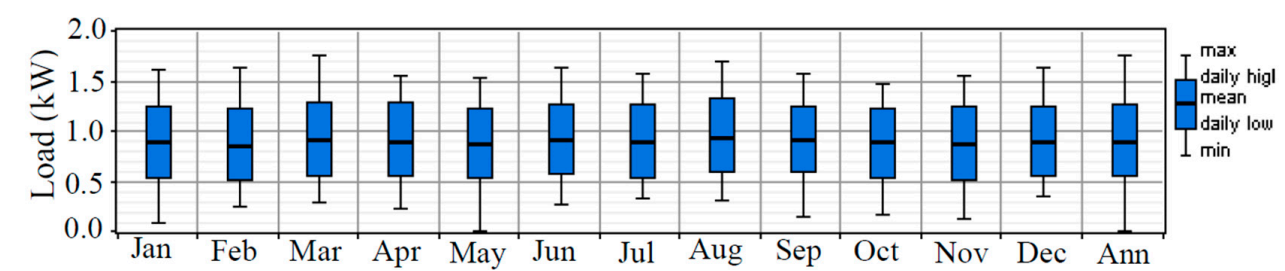

(a) Seasonal DC-load profile

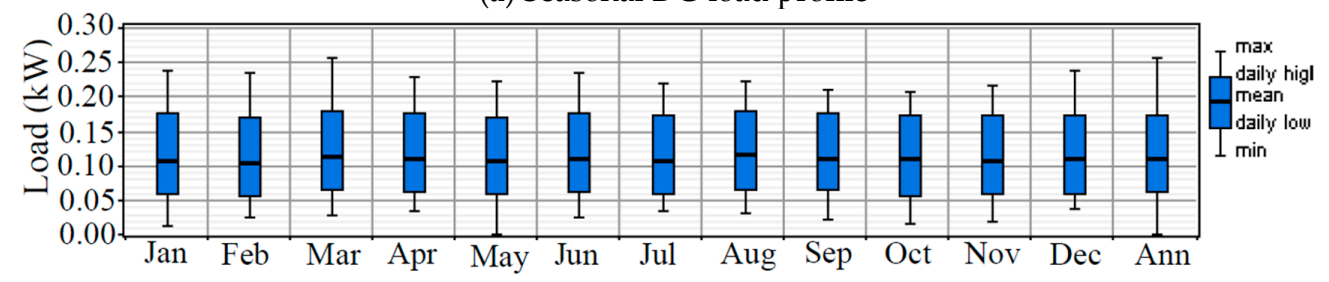

(b) Seasonal AC-load profile

Figure 9. Seasonal load profiles. (a) DC-load profile; (b) AC-load profile. 


\subsection{Characteristics of the Components, Economic Data, and Lifetime of the Project}

To develop the optimal solar power system, several values for the system components, operational lifecycle, component efficiency, and costs are considered for efficient performance in the optimisation process. The lifecycle of the project is 10 years, representing the lifetime of the base station equipment [26]. The South Korea annual real interest rate was 1.25\% in June 2016 [27]. More details about the technical and economic specifications of the system components are listed in Table 2.

Table 2. HOMER simulation setup.

\begin{tabular}{ccc}
\hline Components & Configuration & Value \\
\hline \multirow{2}{*}{ Control parameters } & Annual real interest rate & $1.25 \%$ \\
& Project lifecycle & 10 years \\
\hline PV & Sizes & $5,5.5,6,6.5,7,7.5,8 \mathrm{~kW}$ \\
& Lifecycle & 25 years \\
Efficiency & $90 \%$ \\
Tracking mode & TC & $\$ 1$ per watt \\
& Replacement cost & $\$ 1$ per watt \\
& O\&M cost per year & $\$ 0.01$ per watt \\
\hline Inverter & Sizes & $0.5,1,1.5,2,2.5 \mathrm{~kW}$ \\
& Efficiency & $95 \%$ \\
Lifecycle & 15 years \\
& IC & $\$ 0.4$ per watt \\
& Replacement cost & $\$ 0.4$ per watt \\
& O\&M cost per year & $\$ 0.01$ per watt \\
\hline Trojan L16P & batteries & $24,32,40,48,56,64,72$ \\
& Efficiency & $85 \%$ \\
& Min. lifecycle & 5 years \\
& IC & $\$ 300$ per unit \\
& Replacement cost & $\$ 300$ per unit \\
& O\&M cost per year & $\$ 10$ per unit \\
\hline
\end{tabular}

\subsection{System Implementation}

The implementation of a stand-alone solar power system within the HOMER simulation software and the configurations for the various elements in the system are shown in Figure 10.
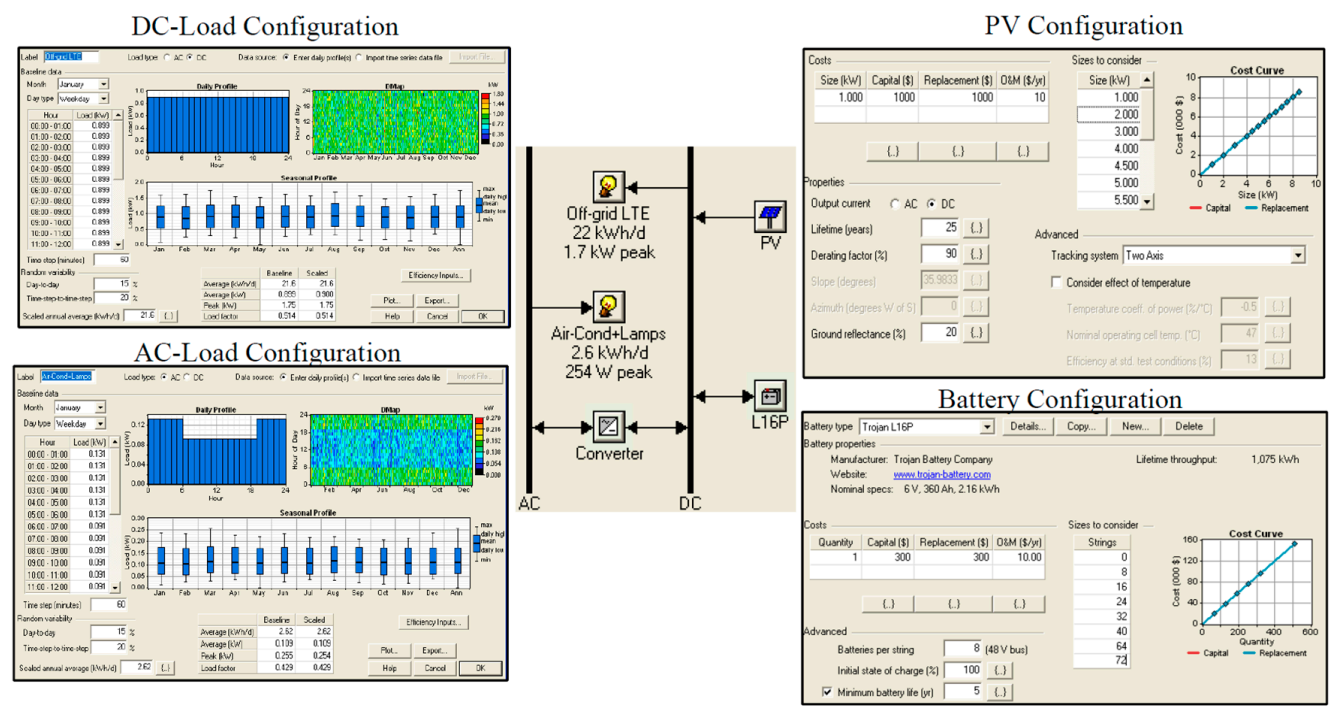

Figure 10. Micro-power system modelling in HOMER. 


\section{Optimisation and Simulation Results}

In this study, different average daily solar radiation values of 4.0, 4.5, 4.6, 4.7, 4.8, 4.9, and $5.0 \mathrm{kWh} \cdot \mathrm{m}^{-2}$ are considered to cover a wide range of South Korean locations. The optimal system architecture, output energy production, technical criteria to implement the proposed solar power system, and cash flow analysis are presented in the following subsections.

\subsection{Optimal System Architecture}

A summary of both of the optimum size of the components and the costs of the solar power system, identified by the HOMER simulation based on the different daily radiation values, are presented in Table 3.

Table 3. Technical and economic criteria for the optimal solar power system.

\begin{tabular}{|c|c|c|c|c|c|c|}
\hline \multicolumn{4}{|c|}{ Optimal Sizing } & \multicolumn{3}{|c|}{ Cost Factors } \\
\hline $\begin{array}{l}\text { Daily Radiation } \\
\left(\mathrm{kWh} \cdot \mathrm{m}^{-2}\right)\end{array}$ & PV (kW) & $\begin{array}{c}\text { Battery } \\
\text { (Unit) }\end{array}$ & $\begin{array}{l}\text { Inverter } \\
(\mathbf{k W})\end{array}$ & IC (\$) & $\begin{array}{c}\text { Annual } \\
\text { O\&M (\$) }\end{array}$ & NPC (\$) \\
\hline 4.0 & 7.5 & 64 & 0.2 & 26,780 & 717 & 29,483 \\
\hline 4.5 & 6.5 & 64 & 0.2 & 25,780 & 707 & 28,919 \\
\hline $4.6-4.8$ & 6.0 & 64 & 0.2 & 25,280 & 702 & 28,638 \\
\hline $4.9-5.0$ & 5.5 & 64 & 0.2 & 24,780 & 697 & 28,356 \\
\hline
\end{tabular}

In general, the optimal size of the solar array decreases with increasing solar radiation. However, in some cases, such as $4.6-4.8 \mathrm{kWh} \cdot \mathrm{m}^{-2}$, the size of the solar array is the same, but the energy output of the solar array is different, as discussed in detail in Section 8.2 "Energy Yield Analysis".

IC is the construction cost of the proposed solar power system, which is paid at the beginning of the project and depends on the components included in the solar power system. The O\&M costs are the annually costs to operate and maintain the system components. Table 3 shows that both the IC and $O \& M$ costs decrease with increasing solar radiation because the size of the solar array decreases. The decrease in both IC and O\&M results in an overall decrease in the total cost of the solar power system (NPC). More details are provided in Section 8.4, "Economic Analysis."

\subsection{Energy Yield Analysis}

Figure 11 shows the annual output energy of the solar power system for different cases of solar radiation. The annual output energy of the solar power system increases with increasing solar radiation at a given PV size.

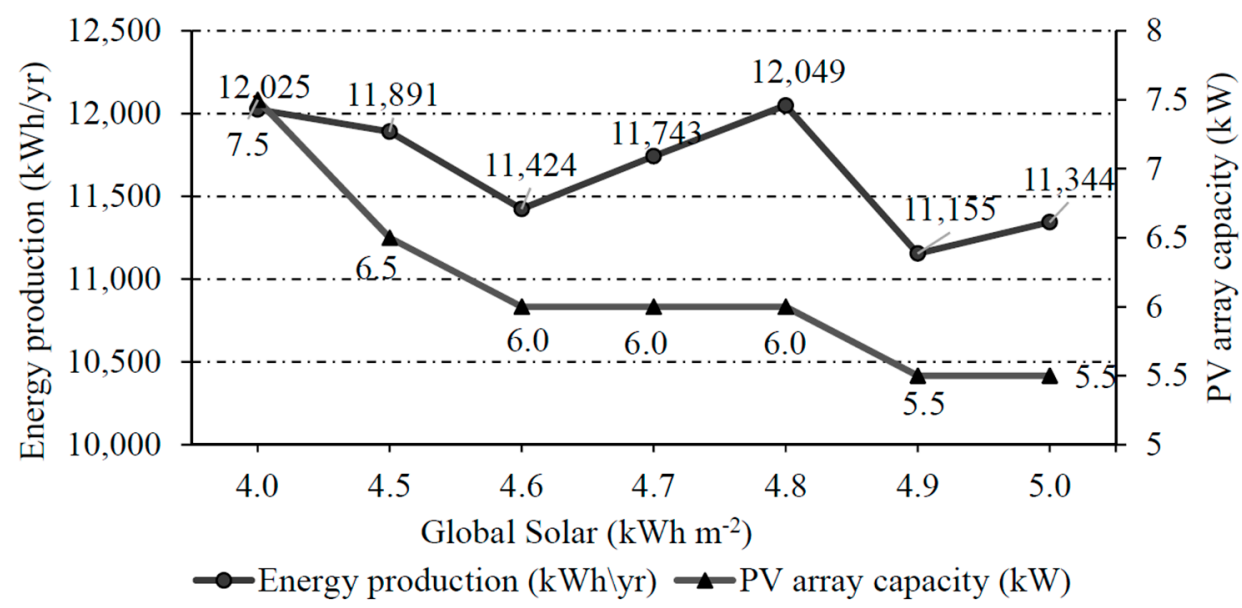

Figure 11. Annual energy production of solar power systems based on different cases of solar radiation. 
The following discussion is based on the average daily solar radiation for South Korea of $4.0 \mathrm{kWh} \cdot \mathrm{m}^{-2}$ as a case study. However, the analysis can be extended to include other cases of solar radiation with slight differences in daily peak sun hours per case.

Based on Equation (2), the annual output energy of the solar power system is $9855 \mathrm{kWh}(7.5 \mathrm{~kW} \mathrm{PV}$ capacity $\times 4.01 \mathrm{~h}$ peak solar hours $\times 0.9 \mathrm{PV}$ derating factor $\times 365$ day/year). The dual tracking mode is used in this study, which increases the annual output energy to $12,025 \mathrm{kWh}$.

The total annual output energy of the solar power system is $12,025 \mathrm{kWh}$, while the LTE-macro base station requires $8840 \mathrm{kWh}$ : AC load (air conditioner $91 \mathrm{~W}+$ lamps $40 \mathrm{~W}$ (operation from $7 \mathrm{p} . \mathrm{m}$. to 7 a.m.) plus the DC load (base station $819 \mathrm{~W}+$ microwave link $80 \mathrm{~W}$ ) multiplied by $(24 \mathrm{~h} \times 365$ days/year). The difference between the annual output energy of the PV array and the annual energy required by the LTE-macro base station is: $2285 \mathrm{kWh} /$ year excess electricity $+850 \mathrm{kWh} /$ year battery losses + $50 \mathrm{kWh} /$ year inverter losses.

Figure 12 shows the monthly power production. The maximum output power occurs in April and May, while the minimum output power occurs in November and December.

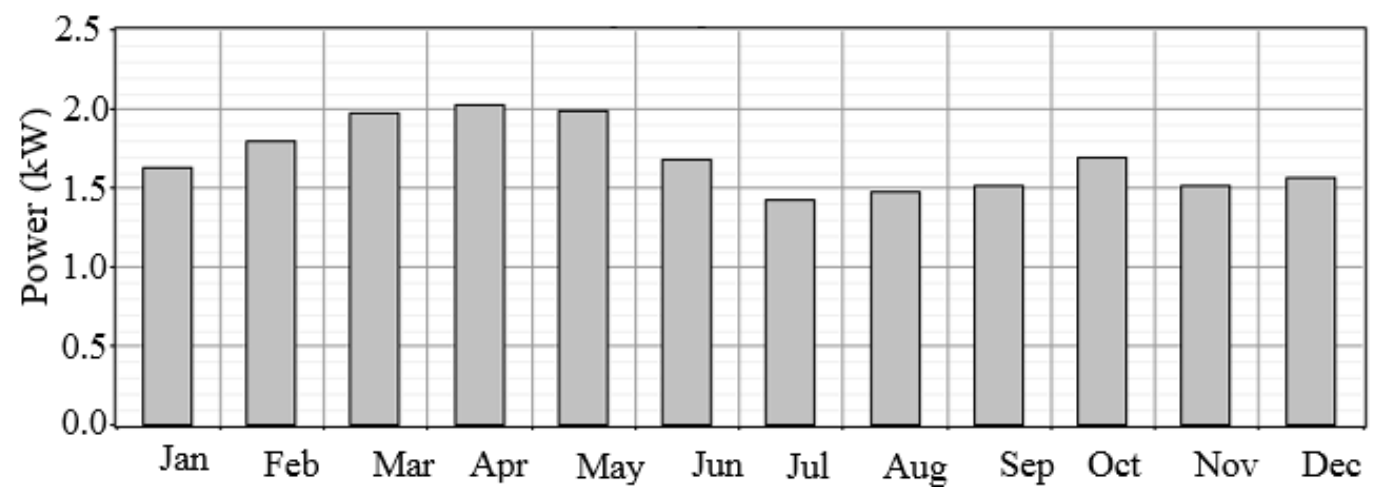

Figure 12. Monthly power production at $4.0 \mathrm{kWh} \cdot \mathrm{m}^{-2}$.

The total number of batteries is 64 . The annual energy-in rate of $5997 \mathrm{kWh}$, multiplied by the efficiency of $85 \%$, gives an annual energy-out rate of $5098 \mathrm{kWh}$. In addition, the amount of time that the battery bank can autonomously supply the LTE-macro base station is 3 days and $23.9 \mathrm{~h}$, which is computed based on Equation (4) (64 batteries $\times 6 \mathrm{~V}$ nominal voltage $\times 360$ Ah nominal capacity $\times$ DOD $0.7 \times 24 \mathrm{~h}$ ) divided by (daily average LTE-macro base station power requirement of $24.22 \mathrm{kWh}$ ). The total battery autonomy divided by the total number of batteries gives the autonomy for one battery, which is $1.5 \mathrm{~h}$. Moreover, the expected battery life is 10 years, as computed by Equation (5). The seasonal statistics of the maximum and minimum state of charge for the battery are given in Figure 13.

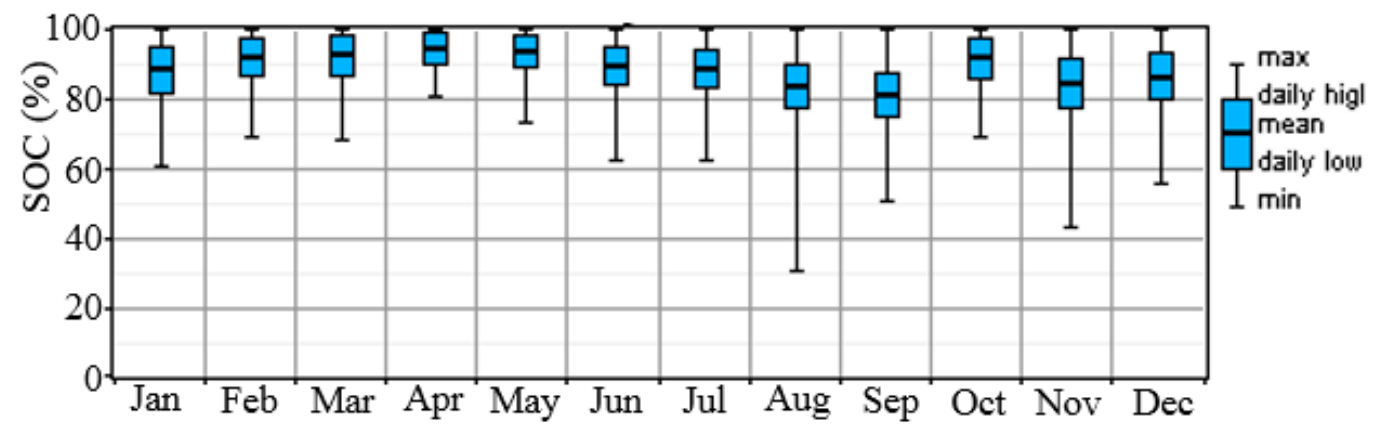

Figure 13. Monthly statistics of the SOC for the battery. 
The inverter annual energy-in rate is $1005 \mathrm{kWh}$ which, when multiplied by the efficiency of $95 \%$, gives an annual energy-out rate of $955 \mathrm{kWh}$, with $8759 \mathrm{~h}$ /year operation (operating hours $24 \mathrm{~h} \times 365$ day/year). The monthly statistics of the output power for the inverter are shown in Figure 14.

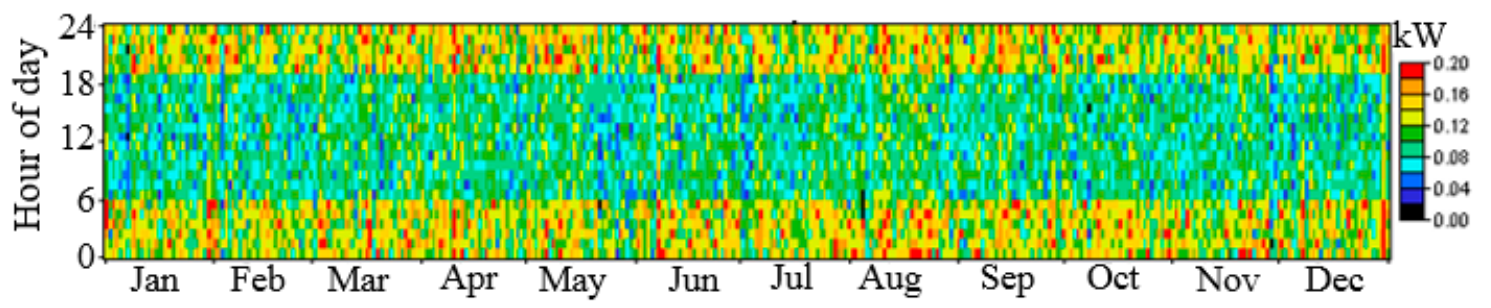

Figure 14. Monthly statistics of the inverter output power.

\subsection{Technical Criteria}

The schematic diagram of the proposed solar energy system for feeding the LTE-macro base station is presented in Figure 15.

The capacity of the PV array is $7.5 \mathrm{~kW}$. The Sharp ND-250QCs module (polycrystalline), with a voltage of $29.80 \mathrm{~V}_{\mathrm{dc}}$, current of $8.40 \mathrm{~A}$, and power of $250 \mathrm{~W}$ is a good choice [28]. The PV array consists of 30 Sharp ND-250QCs modules, connected as five in a series and six in parallel to satisfy the requirements of the solar control regulator, solarcon SPT-4830 [29]: (i) the open circuit voltage for an solar control regulator $\left(192 \mathrm{~V}_{\mathrm{dc}}\right)$ should be higher than the open circuit voltage of a PV array (5 PV modules in series $\times$ open circuit voltage of a Sharp ND-250QCs module $38.3 \mathrm{~V}_{\mathrm{dc}}$ ); and (ii) the current of the solar control regulator $(30 \mathrm{~A})$ should be higher than the short circuit current of a PV array (short circuit current of a Sharp ND-250QCs module $8.90 \mathrm{~A} \times 1.3$ safety factor).

Since the capacity of the PV array is $7.5 \mathrm{~kW}$ and the capacity of the solar control regulator (solarcon $S P T-4830$ ) is $1.6 \mathrm{~kW}$, five solar control regulators are needed. The solar control regulators adapt the output voltage of the PV array from $149 \mathrm{~V}_{\mathrm{dc}}$ ( 5 PV modules in series $\times$ voltage of a Sharp ND-250QCs module $29.80 \mathrm{~V}_{\mathrm{dc}}$ ) to $48 \mathrm{~V}_{\mathrm{dc}}$, which is suitable for the DC bus-bar and battery bank. Herein, the DC bus-bar equals $48 \mathrm{~V}_{\mathrm{dc}}$, which is the input DC voltage to the LTE-macro base station.

The optimal number of batteries is 64 . Since the single battery voltage is $6 \mathrm{~V}_{\mathrm{dc}}$, in order for the battery bank be compatible with the input DC voltage of the bus-bar $\left(48 \mathrm{~V}_{\mathrm{dc}}\right)$, the batteries are connected eight in a series and eight in parallel. The SU200P inverter, with a specification of $200 \mathrm{~W}$, input voltage of $12 / 24 / 48 \mathrm{~V}_{\mathrm{dc}}$, output voltage of $220 / 110 \mathrm{~V}_{\mathrm{ac}}$, and frequency of $50 \mathrm{~Hz} / 60 \mathrm{~Hz}$, is a good choice of inverter.

The system is designed to operate independently of the diesel generator (as discussed in Section 4). However, the diesel generator feeds the base station during maintenance and when the base station demand is higher than the PV array power output or the maximum battery DOD is reached. The required backup diesel generator is approximately $4 \mathrm{~kW}$, which is computed as (LTE-macro base station, AC and DC load $1.1 \mathrm{~kW}$ )/(diesel generator efficiency 30\% [2] $\times$ converter efficiency $95 \%$ ). The AC loads are fed directly from the diesel generator in the case of a solar power system failure, and the DC load feed occurs via a converter (AC/DC). The required converter is $1.2 \mathrm{~kW}$, which is computed as (the maximum LTE-macro base station DC load $899 \mathrm{~W} /$ converter efficiency 95\%) multiplied by a 1.25 safety factor. 


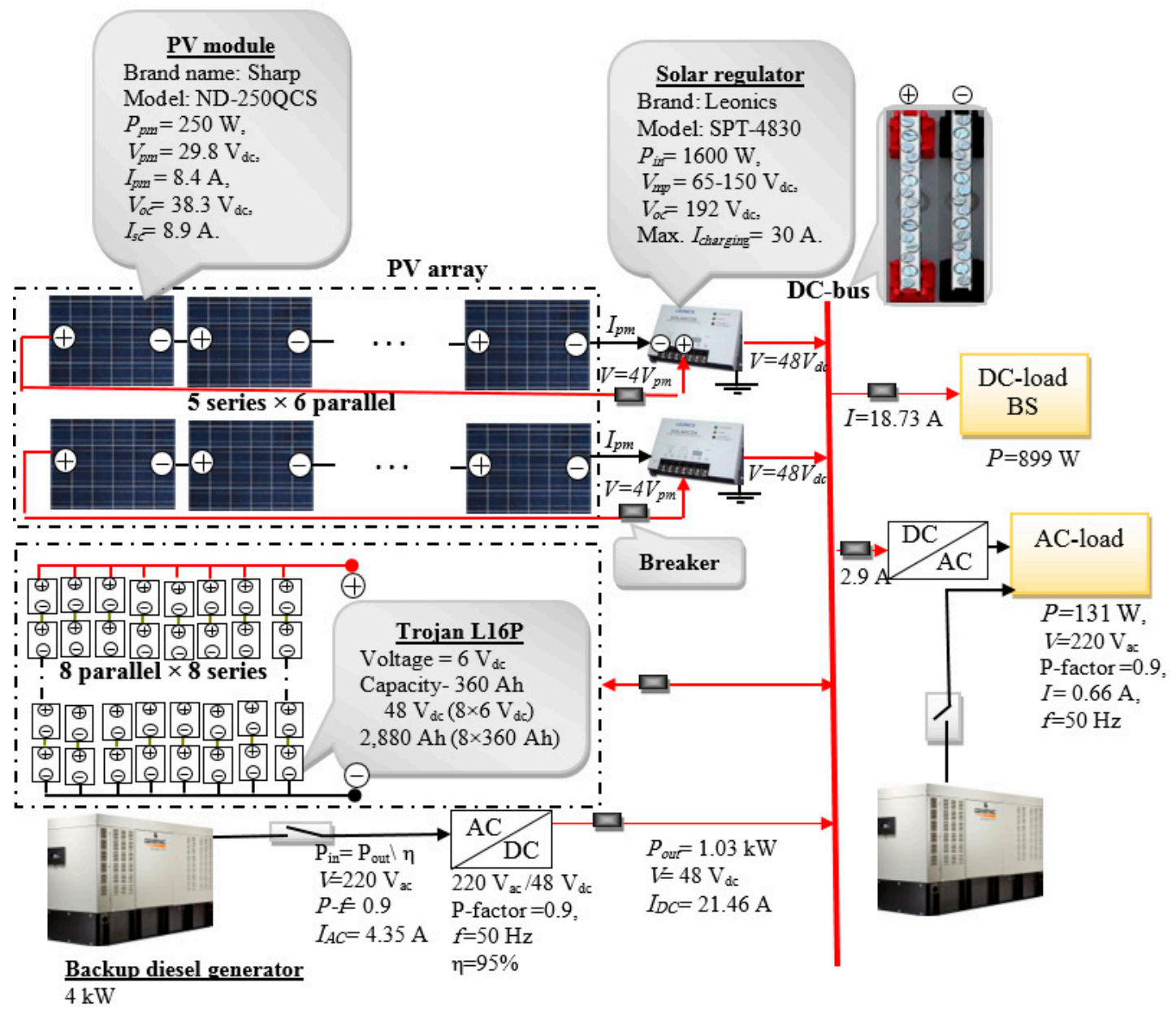

Figure 15. Schematic diagram of the proposed solar power system.

\subsection{Economic Analysis}

The setup cost of the solar power system proposed in this study, based on the characteristics of South Korean solar radiation exposure $\left(4.0 \mathrm{kWh} \cdot \mathrm{m}^{-2}\right)$, is shown in Figure 16. The breakdown for the IC, replacement, O\&M and salvage costs incurred within the project lifetime is given in the following paragraphs.

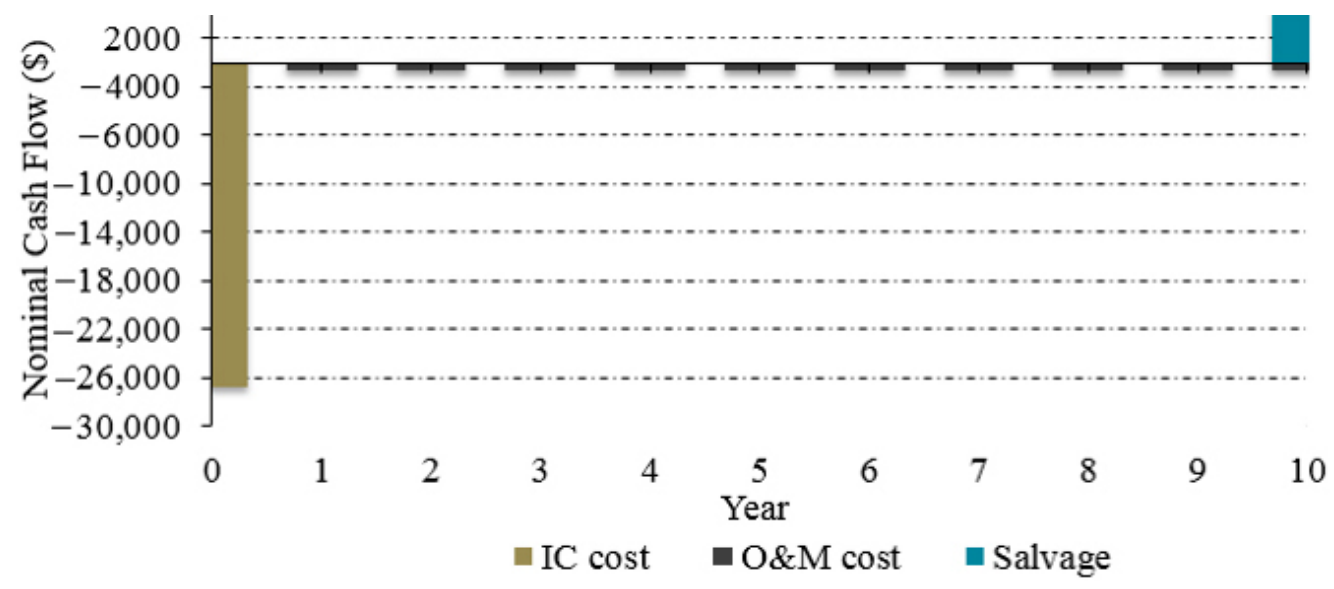

Figure 16. Cash flow summary during the project lifecycle. 
(i) The initial cost for each element of the solar power system is listed in Table 2. In addition, the total initial cost to set up a solar power system is $\$ 26,780$, as shown in Table 3 . The total initial cost details is as follows:

a) The PV costs $\$ 7500(\mathrm{PV}$ size $\mathrm{kW} \times$ initial cost $\$ / \mathrm{kW})$.

b) The battery bank costs $\$ 19,200$ (battery units $\times$ cost $\$ /$ unit).

c) The inverter costs $\$ 80$ (inverter size $\mathrm{kW} \times$ cost $\$ / \mathrm{kW}$ ).

(ii) Table 2 shows the annual cost for the maintenance and operation of different components of the solar power system. Table 3 shows that the total annual maintenance and operation cost is $\$ 717$, and the details are as follows:

a) The PV costs $\$ 75(\mathrm{PV}$ size $\mathrm{kW} \times \mathrm{O} \& \mathrm{M}$ cost $\$ / \mathrm{kW})$.

b) The battery bank costs $\$ 640$ (battery units $\times$ O\&M cost $\$ /$ unit).

c) The inverter costs $\$ 2(0.2 \mathrm{~kW} \times$ cost $\$ 10 / 1 \mathrm{~kW})$.

The largest part of the initial capital and maintenance and operation costs is the battery bank. However, these costs can be reduced if the number of batteries is decreased, but an important issue to consider is the battery bank autonomy, which will decrease if the total number of batteries is decreased.

(iii) The replacement cost is zero because the lifetimes of the PV array and inverter are longer than the project lifecycle. In addition, the battery bank lifetime is 10 years, which equals the project lifecycle.

(iv) The salvage value is computed at the end of the project lifetime and typically applies to components that have longer lifetimes than the project lifecycle. Herein, both the PV and inverter have longer lifetimes, as shown in Table 2 . The total salvage value of the proposed solar power system is \$4527, which is computed based on Equation (9). The details are as follows:

a) The PV cost $\$ 4500\left(\$ 7500 \times\left(\frac{15 y r}{25 y r}\right)\right)$,

b) The inverter cost $\$ 27\left(\$ 80 \times\left(\frac{5 y r}{15 y r}\right)\right)$.

The above economic analysis is based on a nominal system. However, according to Equation (8), Figure 17 shows the yearly discount factor during the project lifecycle.

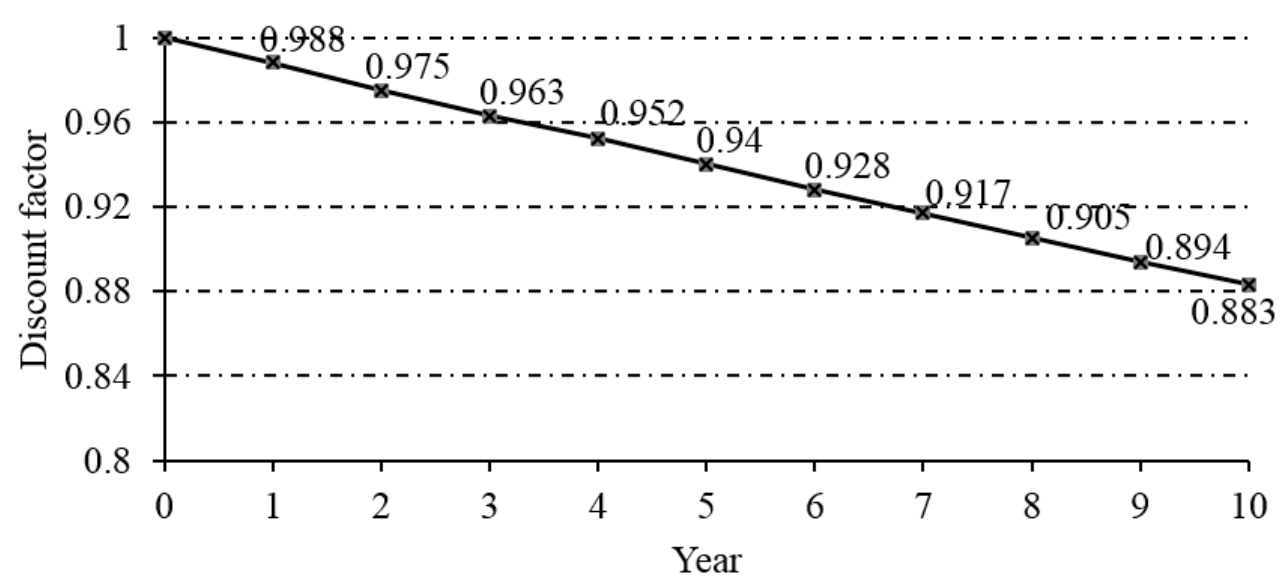

Figure 17. Yearly discount factor during the project lifecycle.

The total NPC is calculated by summing the total discounted cash flows in each year of the project lifetime, as follows: initial capital cost $\$ 26,780+$ O\&M costs $\$ 6701$ - salvage value $\$ 3998$, which equals $\$ 29,483$. Figure 18 summarises the total discounted costs for average daily solar radiation values. 


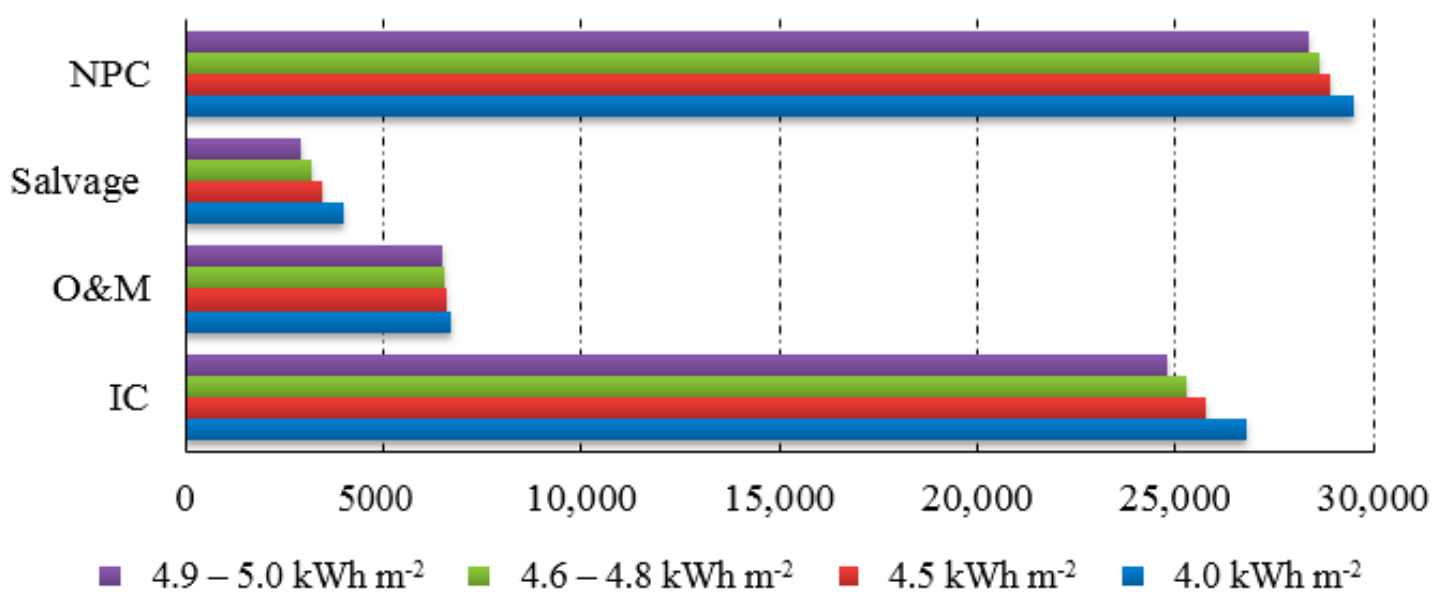

Figure 18. Total discounted costs for solar projects for different average daily solar radiation values.

\section{Economic Feasibility of Using the Proposed Solar Power System Compared with a Diesel Generator}

\subsection{Initial Cost (IC)}

a Traditional power system (diesel generator only): The diesel generator IC cost is (size $4 \mathrm{~kW} \times$ cost $\$ 660 / 1 \mathrm{~kW}$ [2]), equalling $\$ 2640$. However, fossil fuels are not sustainable and are expensive, and the price increases continuously.

b Proposed solar power system: The PV system IC cost is $\$ 26,780$. The IC cost of the PV system is high because the components of the PV system are expensive compared with the diesel generator. However, the global price of PV systems is continuously decreasing.

\subsection{Annual Operation and Maintenance (O\&M) Costs}

a Traditional power system: The LTE-macro base station is fed by diesel generator only. The annual maintenance and operation costs of the diesel generator are up to $\$ 4680$. The details are as follows:

(i) Yearly maintenance cost is $\$ 438$, which is computed as (diesel generator maintenance cost of $\$ 0.05 / \mathrm{h} \times$ annual diesel generator operating hours $8760 \mathrm{~h}$ ).

(ii) Fuel cost is $\$ 4242$, which is computed based on the diesel price of $\$ 1.04 / \mathrm{L}[30] \times$ total diesel consumption of $4079 \mathrm{~L}$ per year. The total diesel consumption is computed based on specific fuel consumption of $0.388 \mathrm{~L} / \mathrm{kWh} \times$ annual electrical production of the diesel generator of $10,512 \mathrm{kWh} /$ year (diesel generator capacity $4 \mathrm{~kW} \times$ diesel generator efficiency $0.3 \times 24 \mathrm{~h} \times 365 \mathrm{~d} /$ year $)$.

b Proposed solar power system: By applying the proposed solar power system, the LTE-macro base station is fed by a stand-alone solar power system. The annual O\&M cost decreases to $\$ 717$ (as discussed in Section 8.4), yielding a savings of $84.67 \%$.

\subsection{Replacement Costs}

a Traditional power system: Cellular operators may need to change the diesel generator every 3 years; thus, the diesel generator will be changed at least three times during the project lifecycle. The total diesel generator replacement cost is $3 \times($ size $4 \mathrm{~kW} \times$ cost $\$ 660 / 1 \mathrm{~kW})$, totalling at least $\$ 7920$.

b Proposed solar power system: There are no replacement costs, as discussed in Section 8.4. 


\subsection{Net Present Cost (NPC)}

a Traditional power system: The total NPC includes the IC costs $\$ 2640+$ O\&M costs $\$ 46,800+$ Replacement costs $\$ 7920$, totalling $\$ 57,360$ over the project lifetime (10 year).

b Proposed solar power system: The NPC, representing the lifecycle cost that occurs within the project lifetime, amounts to $\$ 29,483$.

The total NPC that can be saved by using the proposed solar power system scheme amounts to $48.6 \%$. Figure 19 summarises the operational expenditures of the traditional power system (diesel generator only) compared with the proposed solar power system over the project lifetime (10 year).

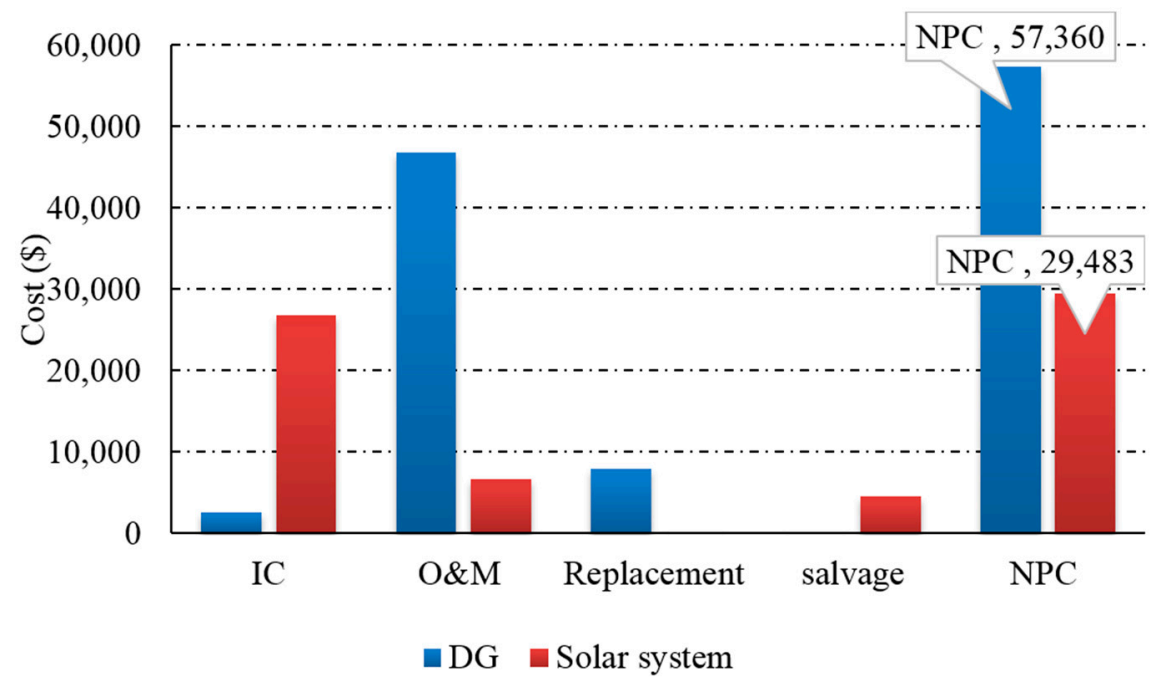

Figure 19. Comparison of the operational expenditures for the proposed solar power system and a diesel generator.

\section{Conclusions and Remarks}

This study discussed the feasibility of remote long-term evolution (LTE)-macro base stations at off-grid sites in South Korea that are powered by solar power systems. Four key aspects have been discussed: (i) optimal system architecture; (ii) energy yield analysis; (iii) technical criteria; and (iv) economic analysis.

The simulation results showed that the solar array can meet the energy requirements of the LTE-macro base station independently without support from the battery bank. The total annual energy output of the solar array is $12,025 \mathrm{kWh}$, which covers the required amount of LTE-macro base station energy and provides $2285 \mathrm{kWh}$ of excess electricity. Moreover, if the solar array fails to support the LTE-macro base station, the battery bank can supply the LTE-macro base station load autonomously for 3 days and $23 \mathrm{~h}$; this is considered to be a sufficient amount of time to fix the solar array. Furthermore, if the batteries reach the maximum depth of discharge (DOD) before the malfunctions in the solar array are fixed, the diesel generator can supply the LTE-macro base station; this is considered to be a rare case because the solar array can cover the load independently.

The simulation results showed that the solar power system can save $48.6 \%$ of the total NPC cost. These results indicate that the solar power system is a good choice for telecommunication to reduce both the operational expenditures and greenhouse gases.

Finally, details of the optimum size of the different solar power system components, technical criteria, and overall cost of the proposed solar power system based on the daily solar radiation of South Korea are summarised in Table 4. 
Table 4. Summary of the technical specifications and costs of the proposed PV system.

\begin{tabular}{|c|c|c|c|c|}
\hline \multicolumn{5}{|c|}{ Average Daily Solar Radiation for South Korea of $4.0 \mathrm{kWh} \cdot \mathrm{m}^{-2}$} \\
\hline \multicolumn{3}{|c|}{ Daily demand load (kWh) } & \multicolumn{2}{|r|}{24.22} \\
\hline \multirow{2}{*}{\multicolumn{3}{|c|}{$\begin{array}{c}\text { Capacity }(\mathrm{kW}) \\
\text { Energy }(\mathrm{kWh} / \text { year })\end{array}$}} & & 7.5 \\
\hline & & & & 12,025 \\
\hline \multirow{6}{*}{ PV } & & $P_{\max }$ & & $250 \mathrm{~W}$ \\
\hline & & $\mathrm{V}_{\mathrm{pm}}$ & & $29.80 \mathrm{~V}_{\mathrm{dc}}$ \\
\hline & Brand model & $\mathrm{V}_{\mathrm{OC}}$ & $\begin{array}{l}\text { Sharp } \\
\text { ND-250OCs }\end{array}$ & $38.3 \mathrm{~V}_{\mathrm{dc}}$ \\
\hline & & $\mathrm{I}_{\mathrm{pm}}$ & & $8.40 \mathrm{~A}$ \\
\hline & & $\mathrm{I}_{\mathrm{sc}}$ & & $8.90 \mathrm{~A}$ \\
\hline & \multicolumn{2}{|c|}{ Interconnected } & \multicolumn{2}{|c|}{5 Series $\times 6$ Parallel } \\
\hline \multirow{6}{*}{ SCR } & & $P_{\max }$ & & $1.6 \mathrm{~kW}$ \\
\hline & & $\mathrm{V}_{\mathrm{pm}}$ & & $65-150 \mathrm{~V}_{\mathrm{dc}}$ \\
\hline & Brand model & $\mathrm{V}_{\mathrm{OC}}$ & Solarcon & $192 \mathrm{~V}_{\mathrm{dc}}$ \\
\hline & & $\mathrm{V}_{\text {out }}$ & & $48 \mathrm{~V}_{\mathrm{dc}}$ \\
\hline & & $I_{\max }$ & & $30 \mathrm{~A}$ \\
\hline & \multicolumn{2}{|c|}{ Total Regulators } & \multicolumn{2}{|r|}{5} \\
\hline \multirow{7}{*}{ Battery } & & $(\mathrm{V})$ & \multirow{3}{*}{ Trojan L16P } & Nominal voltage $6 \mathrm{~V}$ \\
\hline & Brand model & (Ah) & & Nominal current $360 \mathrm{Ah}$ \\
\hline & & $(\mathrm{kWh})$ & & Nominal capacity $2.16 \mathrm{kWh}$ \\
\hline & \multicolumn{2}{|c|}{ Total batteries } & \multicolumn{2}{|c|}{64} \\
\hline & \multicolumn{2}{|c|}{ Interconnected } & \multicolumn{2}{|c|}{8 Series $\times 8$ Parallel } \\
\hline & \multicolumn{2}{|c|}{ Autonomy (h) } & \multicolumn{2}{|r|}{95.9} \\
\hline & \multicolumn{2}{|c|}{ Lifetime (year) } & \multicolumn{2}{|r|}{10} \\
\hline Inverter & \multicolumn{2}{|c|}{ Capacity $(\mathrm{kW})$} & \multicolumn{2}{|r|}{0.2} \\
\hline \multirow{4}{*}{$\begin{array}{l}\text { NPC (\$) with } \\
\text { discount factor }\end{array}$} & & & \multirow{4}{*}{29,483} & 26,780 \\
\hline & O\& & & & 6701 \\
\hline & Replac & & & 0 \\
\hline & Salv & & & 3998 \\
\hline
\end{tabular}

Acknowledgments: This work was supported by the faculty research fund of Sejong University in 2016. We thank the reviewers for the fruitful suggestions, which helped us to improve the quality of this work.

Author Contributions: Mohammed H. Alsharif analysed the data and completed the first draft, and Jeong Kim wrote about the potential of applying solar energy in South Korea part and revised the final version of paper.

Conflicts of Interest: The authors declare no conflict of interest.

\section{Abbreviations}

The following abbreviations and symbols are used in this manuscript:

Abbreviation
CDMA
$\mathrm{CO}_{2}, \mathrm{NO}_{x}, \mathrm{SO}_{2}$
$\mathrm{CRF}$
DG
DOD
FC
GHG
GSM
HOMER
IC
KMA
LTE

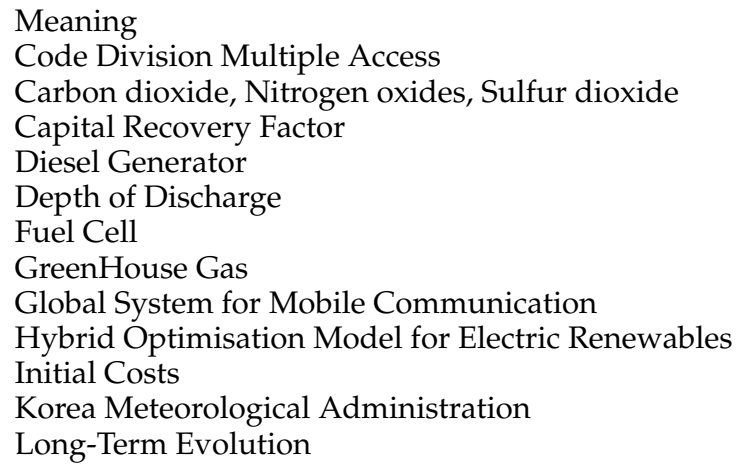




\begin{tabular}{|c|c|}
\hline Abbreviation & Meaning \\
\hline MSW & Modified Sine-Wave \\
\hline NPC & Net Present Cost \\
\hline NREL & National Renewable Energy Laboratory \\
\hline O\&M & Operation and Maintenance Costs \\
\hline PV & PhotoVoltaic \\
\hline SCR & Solar Control Regulator \\
\hline SOC & State of Charge \\
\hline TAC & Total Annualised Cost \\
\hline$P_{o p}$ & BS operating power \\
\hline$P_{P A}^{D C}$ & Power consumed by power amplifier \\
\hline$P_{R F}^{D C}$ & Radio frequency power \\
\hline$P_{B B}^{D C}$ & Baseband power \\
\hline$P_{t x}^{\max }$ & BS transmission power \\
\hline$P_{0}$ & Normalised BS transmission power \\
\hline$P_{B S}$ & Total Power Consumption for the BS \\
\hline$P_{m c}$ & Microwave backhaul power \\
\hline$P_{l m}$ & Auxiliary equipment power \\
\hline$\sigma_{D C}$ & DC-DC power supply losses \\
\hline$\sigma_{\text {cool }}$ & Cooling losses \\
\hline$N_{T R X}$ & Number of transceivers \\
\hline$\eta_{P A}$ & PA efficiency \\
\hline$\alpha$ & Path loss coefficient \\
\hline$R_{o}$ & Coverage radius \\
\hline$E_{P V}$ & Energy output of the PV array \\
\hline$Y_{P V}$ & Rated capacity of the PV array \\
\hline$f_{P V}$ & PV derating factor \\
\hline$A_{\text {batt }}$ & Battery bank autonomy \\
\hline$N_{\text {batt }}$ & Number of batteries \\
\hline$V_{\text {nom }}$ & Nominal voltage of a single battery \\
\hline$Q_{\text {nom }}$ & Nominal capacity of a single battery \\
\hline$L_{\text {prim,ave }}$ & Average daily LTE-macro BS load \\
\hline$R_{\text {batt }}$ & Battery bank lifetime \\
\hline$Q_{\text {lifetime }}$ & Lifetime throughput of a single battery \\
\hline$Q_{\text {thrpt }}$ & Annual battery throughput \\
\hline$R_{\text {batt }, f}$ & Battery float life \\
\hline
\end{tabular}

\section{References}

1. Alsharif, M.H.; Nordin, R.; Ismail, M. Classification, recent advances and research challenges in energy efficient cellular networks. Wirel. Pers. Commun. 2014, 77, 1249-1269. [CrossRef]

2. Kusakana, K.; Vermaak, H.J. Hybrid Renewable Power Systems for Mobile Telephony Base Stations in Developing Countries. Renew. Energy 2013, 51, 419-425. [CrossRef]

3. Solangi, K.H.; Islam, M.R.; Saidur, R.; Rahim, N.A.; Fayaz, H. A review on global solar energy policy. Renew. Sustain. Energy Rev. 2011, 15, 2149-2163. [CrossRef]

4. Korea Meteorological Administration (KMA). Annual Climatological Report 2013. Available online: http:/ /www.kma.go.kr/weather/observation/data_monthly.jsp (accessed on 12 July 2016).

5. NASA Web Site. Available online: https://eosweb.larc.nasa.gov/cgi-bin/sse/homer.cgi?email=skip\%40larc. nasa.gov\&step=1\&lat=37.499\&lon=126.54958\&submit=Submit\&ms=1\&ds=1\&ys=1998\&me=12\&de=31\& ye $=1998 \&$ daily $=$ swv_dwn (accessed on 12 July 2016).

6. Green Power for Mobile (GSMA). Community Power Using Mobile to Extend the Grid. Available online: http://www.gsma.com/mobilefordevelopment/wp-content/uploads/2012/05/CommunityPower-Using-Mobile-to-Extend-the-Grid-January-2010.pdf (accessed on 12 July 2016).

7. Schmitt, G. The Green Base Station. In Proceedings of the 4th International Conference on TelecommunicationEnergy Special Conference (TELESCON), Vienna, Austria, 10-13 May 2009; pp. 1-6. 
8. John, P. Let It Shine: The 6000 Year Story of Solar Energy; Revised Edition; New World Library: Novato, CA, USA, 2013; Chapter 23.

9. Nema, P.; Nema, R.; Rangnekar, S. Minimization of Green House Gases Emission by Using Hybrid Energy System for Telephony Base Station Site Application. Renew. Sustain. Energy Rev. 2010, 14, 1635-1639. [CrossRef]

10. Rath, S.; Ali, S.; Iqbal, M.N. Strategic Approach of Hybrid Solar-Wind Power for Remote Telecommunication Sites in India. Int. J. Sci. Eng. Res. 2012, 3, 1-6.

11. Anayochukwu, A.V.; Nnene, E.A. Simulation and Optimization of Hybrid Diesel Power Generation System for GSM Base Station Site in Nigeria. Electron. J. Energy Environ. 2013, 1, 37-56. [CrossRef]

12. Imtiaz, A.W.; Hafeez, K. Stand Alone PV System for Remote Cell Site in Swat Valley. In Proceedings of the 1st International Conference on Technology and Business Management, Lahore, Pakistan, 28-29 March 2013.

13. Moury, S.; Khandoker, N.M.; Haider, M.S. Feasibility Study of Solar PV Arrays in Grid Connected Cellular BTS Sites. In Proceedings of the IEEE International Conference on Advances in Power Conversion and Energy Technologies (APCET), Mylavaram, India, 2-4 August 2012.

14. Martínez-Díaz, M.; Villafáfila-Robles, R.; Montesinos-Miracle, D.; Sudrià-Andreu, A. Study of Optimization Design Criteria for Stand-alone Hybrid Renewable Power Systems. In Proceedings of the International Conference on Renewable Energies and Power Quality (ICREPQ '13), Bilbao, Spain, 20-22 March 2013.

15. Kaldellis, J. Optimum hybrid photovoltaic-based solution for remote telecommunication stations. Renew. Energy 2010, 35, 2307-2315. [CrossRef]

16. Serincan, F. Reliability considerations of a fuel cell backup power system for telecom applications. J. Power Sources 2016, 309, 66-75. [CrossRef]

17. Aris, A.M.; Shabani, B. Sustainable power supply solutions for off-grid base stations. Energies 2015, 8, 10904-10941. [CrossRef]

18. GPP System Standards. Available online: http://www.3gpp.org/news-events/3gpp-news/1614-sa_5g (accessed on 12 July 2016).

19. LTE in Korea. Available online: http://www.netmanias.com/en/post/reports/6060/kt-korea-lg-u-lte-lte-ask-telecom-wideband-lte/lte-in-korea-2013 (accessed on 12 July 2016).

20. Koo, C.; Hong, T.; Lee, M.; Park, H.S. Estimation of the Monthly Average Daily Solar Radiation using Geographic Information System and Advanced Case-Based Reasoning. Environ. Sci. Technol. 2013, 47, 4829-4839. [CrossRef] [PubMed]

21. Imran, M.; Katranaras, E.; Auer, G.; Blume, O.; Giannini, V.; Godor, I.; Jading, Y.; Olsson, M.; Sabella, D.; Skillermark, P. Energy Efficiency Analysis of the Reference Systems, Areas of Improvements and Target Breakdown; EC-IST Office: Brussels, Belgium, 2011.

22. Auer, G.; Giannini, V.; Desset, C.; Godor, I.; Skillermark, P.; Olsson, M.; Imran, M.A.; Sabella, D.; Gonzalez, M.J.; Blume, O. How much energy is needed to run a wireless network? IEEE Wirel. Commun. 2011, 18, 40-49. [CrossRef]

23. Lambert, T.; Gilman, P.; Lilienthal, P. Micropower System Modeling with HOMER. 2006. Available online: http://homerenergy.com/documents/MicropowerSystemModelingWithHOMER.pdf (accessed on 12 July 2016).

24. Borhanazad, H.; Mekhilef, S.; Saidur, R.; Boroumandjazi, G. Potential Application of Renewable Energy for Rural Electrification in Malaysia. Renew. Energy 2013, 59, 210-219. [CrossRef]

25. Trojan Battery Incorporation. Available online: http://www.trojanbattery.com/ (accessed on 12 July 2016).

26. Ge, X.; Cheng, H.; Guizani, M.; Han, T. 5G wireless backhaul networks: Challenges and research advances. IEEE Netw. 2014, 28, 6-11. [CrossRef]

27. The Bank of Korea Monetary Policy. Available online: http://www.bok.or.kr/baserate/baserateList.action? \%20menuNaviId=33 (accessed on 12 July 2016).

28. Sharp Solar Electricity Incorporation. Available online: http://www.sharpusa.com/SolarElectricity.aspx (accessed on 12 July 2016). 
29. Leonics Incorporation, SolarCon SPT-Series. Available online: http://www.leonics.com/product/ renewable/solar_charge_controller/dl/spt-074.pdf (accessed on 12 July 2016).

30. Global Petrol Prices. Available online: http://www.globalpetrolprices.com/South-Korea/diesel_prices/ (accessed on 12 July 2016).

(c) 2016 by the authors; licensee MDPI, Basel, Switzerland. This article is an open access article distributed under the terms and conditions of the Creative Commons Attribution (CC-BY) license (http:/ / creativecommons.org/licenses/by/4.0/). 